\title{
PENUMPUKAN SAMPAH PLASTIK YANG SULIT TERURAI BERPENGARUH PADA LINGKUNGAN HIDUP YANG AKAN DATANG
}

\author{
Syifa Evania Farin \\ Program studi Pendidikan IPS Fakultas Keguruan dan Ilmu Pendidikan \\ Universitas Lambung Mangkurat \\ Banjarmasin \\ e-mail: Syifaevamia08@gmail.com
}

\begin{abstract}
ABSTRAK
Sampah plastik merupakan sisa limbah yang sangat sulit terurai, plastik adalah Bahan dari organic yang memiliki sifat mudah dibentuk ke bentuk apa saja jika terkena panas dan daya tekan yang kuat. Sampah plastik sangat sulit sekali terurai para ahli dan para pakar memperkirakan sampah plastik membutuhkan waktu 500 sampai 1.000 tahun agar dapat terurai. Bahan plastik sendiri sangat familiar bagi kehidupan manusia bahkan hamper setiap hari setiap manusia pasti menggunakan bahan plastik. dan menyumbangkan berjuta-juta sampah plastic setiap harinya, bahkan di Negara Indonesia sendiri menempati kedudukan kedua dengan sampah plastik domestik yang bisa mencapai hingga 5,4 juta ton per tahunnya, tidak dapat dipungkiri jika sampah plastic akan terus tertumpuk.tujuan penulisan artikel ini untuk menambah wawasan mengenai sampah plastic mulai dari bahaya dan dampak yang ditimbulkan. Menggunakan metode penulisan yang mudah dipahami sehingga dapat dengan mudah memahami bahaya dari sampah plastic.
\end{abstract}

Kata kunci: Sampah plastik, limbah plastik, sampah, masalah lingkungan

\section{PENDAHULUAN}

Permasalahan sampah plastik sudah tidak asing lagi di kehiduupan manusia, banyak para ahli memikirkan cara bagaimana caranya agar sampah platik ini tidak semakin banyak dan tertimbun. Plastik merupakan berbahan dasar minyak bumi dan dengan ditambah dengan bahan dasar lainya yang tidak dapat terurai. Tidak seperti limbah dari buah, rumput, maupun kayu yang dapat terurai dengan carai melalui proses biodegradasi jika tertimbun didalam tanah, yang dimana bahan-bahan tersebut mengalami penguraian, bahan-bahan tersebut di ubah dengan bakteri di tanah dengan melalui beberapa proses sehingga menjadi senyawa yang berguna (Ratya \& Herumurti., 2017).

Samapah yang sehari-hari dihasilkan dari berbagai aktivitas manusia ialah sampah organik dan non organik. Sampah yang dihasilakan dari sampah organik sekitar $60-70 \%$, sedangkan dari sampah nonorganik 30-40\%, sementara itu sampah dari non organik memiliki komposisi sampah plastik sebanyak 14\%. Berat nya yang ringan mudah di bawa serta harganya yang relatif murah menjadikan alasan kenapa bahan plastic lebih sering digunakan bandingkan 
dengan bahan yang lain (Kholidah dkk, 2018; Dokhikhah dkk, 2015; Trihadiningrum dkk, 2006).

Sampah plastik merupakan salah satu dari masalah lingkungan yang ada diberbagai kota-kota besar dipenjuru dunia termasuk di Negara Indonesia. Sampah plastik dapat menyebabkan pencemaran lingkungan apalagi saat ini jumlahnya yang terlalu banyak. Sampah plastic sangat susah sekali terurai, memerlukan bertahun-tahun agar bisa terurai. Sampah plastic yang ada di dalam tanah sangat sulit dan tidak bisa terurai oleh mikroorganisme dapat menyebabkan mineral-mineral yang ada didalam tanah baik itu organik maupun yang non organik lama kelamaan semakin berkurang, hal tersebut menyebabkan jaringan fauna yang ada di tanah seperti cacing dan mikrorganisme lainya yang berada pada area tanah tersebut sulit untuk memproleh makan dan tempat untuk berlindung. Selain itu juga kadar $\mathrm{O}_{2}$ yang ada di dalam tanah semakin sedikit, hal ini dapat menyebabkan fauna tanah kesulitan untuk bernafas dan mati. Selain fauna yang ada didalam tanah, hal ini juga berdampak pada tumbuh-tumbuhan yang ada disekitar area tersebut (Budiyantoro, 2010).

Pemasalahn sampah plastic ini merupakan masalah yang sanagt sulit terselesaikan dan diatasi hingga kini, sementara itu dengan adanya pertumbuhan penduduk yang semakin meningkat maka volume pertumbuhan sampah plastic juga akan semakin banyak dari berbagai aktivitas manusia. Sampah akan terus bertambah selama populasi manusia masih ada, maka dari itu yang dapat kita lakukan adalah mencari Langkah-langkah dan strategi bagaiman sampah plastic bisa di atasi demgan baik. Apabila sampah tersebut tidak segera diatasi dengan baik dan dengan efektif dan efisien, bahaya dan eksistensi sampah akan menghancurkan lingkungan hidup. Permasalah sampah adalah masalah yang krusial. Hingga dapat dikatakan bahwa sampah sebagai masalah kultural, hal ini diakibatkan karena dampaknya yang langsung terkena pada berbagai sisi kehidupan (Nurhayati, 2013).

Sampah plastic sangat mudah terbakar akan tetapi sangat tidak baik jika hal ini terjadi, ada banyak berbagai dampak yang terjadi jika membakar plastic bahkan bisa terjadi kebakaran karena sifatnya yang sangat mudah terbakar. Asap yang terkandung dari hasil pembakaran sampah plastic memiliki kandungan yang sangat berbahaya, karena didalamnya terdapat gas gas beracun yang mengandung karbon monoksida $(\mathrm{CO})$ dan hidrigen sianida $(\mathrm{HCN})$. Adapun kandungan yang terkandung dari hydrogen sianida bersumber dari polimer yang berbahan dasar akrilonitril, dan karbon monoksida marupakan hasil pembakaran yang tidak sempurna. Itulah mengapa sampah plastic merupakan salah satu sumber dari pencemaran udara dan juga dapat berdampak jangka Panjang dan ber efek pada pemanasan global dan atmosfer bumi. Selain itu 
juga bisa berdampah buruk bagi keidupan manusia. Saat ini dari berbagai industry dunia telah menggunakan sampah plastic sebagai alat kemas produk. Banyak dari mereka menggunakan palstik jenis aluminium foil dan plastic multiplayer sebagai pengemasan, plastic jenis ini di percaya aman terhadap produk agar tetap layak di konsumsi. Sebelum adanya kantong plastic ada, manusia pada zaman dulu menggunakan tas dari bahan alam seperti daun, rajutan akar, dan kain. Namun saat Ini banyak orang walaupun sudah membawa tas yang besar tetapi tetap saja meminta kanting plastic. Pada saat ini plastic sudah menjadi gaya hidup. Pada sejauh ini keterlibatan para masyarakat dalam mengurangi dan menghindari dari penggunaan plastic sampah masih sangat rendah. Banyak masyarakat yang masih belum sadar akan bahaya plastic sampah ini bagi masa depan lingkungan hidup. Masih banyak yang dapat kita lakukan agar agar mencegah sampah plastic yang semakin menumpuk dari masa ke masa. (Jatmiko dkk, 2018).

Perlu adanya edukasi terus menerus mengenai bahaya sampah kepada masyarakat agar sadar apa dampak besar dari penumpukan sampah yang semakin tahun semakin bertambah jumlahnya. Penulisan artikel ini merupakan salah satu upaya agar menambah wawasan mengenai sampah plastic dan bahaya-bahaya yang ditimbulkan. Bertujuan agar semakin banyak yang akan bahaya sampah yang timbul di masa yang akan dating.

\section{METODE}

Penulis dalam memproleh dan mengumpulkan data pada daftar Pustaka menggunakan metode data sekunder ialah dengan mencari dan mendapatkan informasi dari pihak lain, tidak secara langsung diproleh dari subjek. Pada data skunder biasanya berbentuk data laporan yang sudah ada. Data sekunder merupakan data yang diproleh melalui jurnal, artikel, dan buku.

Medote yang digunakan penulis dalam menganalisis data merupakan metode deskriptif yakni menyampaikan dan menyajikan data dalam bentuk sistematis agar dapat dengan mudah dipahami.

\section{PEMBAHASAN}

Plastik memiliki keunggulan untuk dapat dibentuk ke berbagai macam bentuk dan ukuran apabila bahan plastic tersebut terpapr suhu yang panas dan dengan di tambah dengan tekanan. Plastic dapat dibentuk menjadi lambaran, Batangan, maupun blok, dan jika dalam bentuk produk seperti botol, bungkusan makanan, alat-alat makan, pipa, dan lainya. Komposisi dari plastic ialah mengandung material zat additive dan polymer lainya. (Waaste management information, 2004).

Plastik merupakan jenis material yamg pada awalnya gunakan dan dikembangkan sejak 
abad ke-20, pada tahun 1975 dan awalnya diperkenalkan oleh Montgomery Ward, Sears, J.C Penny, Jodan Marsh dan beberapah tokoh dunia lainya (Marpaung, 2009). Perkembangan plastic sangat luar biasa yang awal mulanya hanya ratusan ton pada tahun 1930 an, hingga 150 juta ton tahun 1990 an dan melunjak sampai 220 ton pada tahun 2005. Dan hingga kini hampir diseluruh perbelanjaan menggunakan kantung plastic (Anonim, 2009).

Plastik dapat bagi menjadi 2 macam, yakni thermosetting dan thermoplastic. Kedua jenis ini memiliki sifat dan karakteristik yang berbeda. Thermosetting merupakan bahan plastic yang jika sudah di bentuk menjadi padat maka tidak bisa di cairkan lagi dengan cara apapun maupun dengan cara dipanaskan. Sedangkan thermoplastic merupakan bahan plastic yang akan cair jika dipanaskan hingga suhu tertentu dan dapat dibentuk Kembali sesuai dengan keinginan. Secara sederhananya, sampah dapat diartikan sebagai materi, benda, bahan yang tidak diinginkan keadaannya, baik itu yang sisa maupun hasil buangan. Dalam pengertian sampah merupakan sebagai bahan sisa yang dibuang yang merupakan hasil dari aktivitas yang manusia lakukan maupun alam yang telah tidak terpakai dan digunakan lagi karena fungsi utanmnya telah digunakan. Dari sudut pandang lain yang, dalam sudut pandang ekonomi contohnya, sampah dapat diartikan sebagai sisa-sisa bahan yang telah mengalami perlakuan, baik itu karena telah diambil unsur utamanya, pengolahan, maupun karena telah tidak ada manfaatnya yang diproleh dari segi ekonomis dam sudah tidak ada harganya. Atau dapat juga diartikan sebagai sesuatu yang telah terbuang tetapi tidak ada nilai ekonominya. (Das \& Pandey, 2007; Surono, 2013)

Sampah merupakan limbah yang berbentuk padat dan terdiri dari bahan organik dan bahan anorganik yang dianggap tidak memiliki nilai guna dan harus dikelola agar tidak memiliki dampak yang berbahaya bagi lingkungan. Dari segi lingkungan sangat membahayakan bagi lingkungan hidup. Dalam Bahasa kamus lingkungan hidup, sampah memiliki arti sebagai bahan yang tidak memiliki nilai guna dan tidak berharga, Sumber dari timbunan sampah berasa dari kegitan-kegiatan penghasil sampah seperti, rumah tangga, pasar, kegiatan perkotaan, danh fasilitas umum yang lain. Dan kegiatan lainya seperti industry dengan penghasil limbah sampah. Dan secara umum sumber sampah yang terdapat di masyarakat memiliki kaitan erat dengan memanfaatkan lahan pembangunan yaitu TPA maupun TPS. Dari sampah tersebut dakat di klasifikasikan yakni; institusi, komrsil, pelayanan jasa dan kantoran, kontruksi dan pembangunan, industry, pertanuan maupun perkebunan, dan unit pengolahan. (Nurhayari, 2013). 
Banyak tempat yang menjadi penyebab timbulnya plastic yakni dari masyarakat dan permukiman penduduk maupun sampah yang ditimbulkan dari tempat umum seperti pedagang dan lainya. Hal tersebut menjadi bukti bahwa manusia tidak bisa lepas dengan sampah. Terlebih dari penumpukan sampah yang ada pada tempat umum, contohnya seperti pasar dan tempat ramai lainya yang padat dan aktivitas yang tinggi.

Penggunaan plastic Sekarang ini sudah tidak dapat dipisahkan dari kehidupan manusia, kebutuhan akan plastic semakin hari semakin meningkat. Hal ini disebabkan karena plastic merupakan bahan yang mudah dan praktis digunakan sebagai pembungkus atau wadah lainya. Selain praktis dan terlihat bersih tetapi juga sangat mudah ditemukan, plastic juga memiliki daya tahan lama dengan harga yang sangat terjangkau. Tetapi dibaling itu semua banyak masyarakat yang tidak tau bahaya dan dampak dari penggunaan plastic (Nasiri 2004).

Perkembangan yang terus menerus berubag menjadikan industry polimer sintetik semakin pesat. Hal ini membuat kehidupan manusia selalu disajikan dengan kepraktisan dan kenyamanan dari produk yang telah dihasilkan. Contohnya adalah plastic. Kebanyakan plastic seperti berjenis PVC agar memiliki sifat pelembut dan tidak bersifat kaku, maka di tambahkan bahan pelembut. Adapun contoh bahan pelembutnya adalah di(2-ethylhexyl)adipate (DEHA), epoxidized soybean oil (ESBO) dan i(2-ethylhexyl) phthalate (DEHP) juga bifenil poliklorin (PCB), acetyl tributyl citrate (ATBC).

Beberapa bahan pelembut tersebut sangat berbahaya bagi Kesehatan bahkan sampai menyebabkan kematian, sebagai salah satu contohnya yaitu penggunaan bahan pelembut berjenis PCB, di dalam kandungan nya yang berbahaya dapat menyebabkan kematian pada jaringan dan kanker dalam tubuh manusia(karsinogenik), oleh karena itu sekarang sudah banyak dilarang.

Contoh lain dari penggunaan plastic yang menggunakan bahan pelembut yang berbahaya adalah berjenis DEHA. Para peneliti Amerika Serikat mengatakan plastic PVC yang menggunakan bahan pelembut berjenis DEHA jika digunakan pada makanan maka akan mengkontaminasi makanan tersebut.

Adapun satu lagi hal yang perlu diwaspadai dari penggunaan plastic dalam idustri makanan yaitu adanya kontaminasi zat warna plastic dalam makanan. Sebagai contohnya adalah penggunaan kantong plastic kresek untuk membungkus makanan seperti gorengan dan lainnya. Menurut beberapa ahli kimia, zat perwarna hitam yang digunakan jika terkena panas maka bisa terurai dan terdegradasi menuju bentuk radikal yang menyebabkan penyakit. 
Beberpa dampak yang terjadi pada lingkungan ialah tercemarnya tanah, air yang ada didalam tanah, dan fauna yang hidup didalam tanah. Racun yang ada di partikel plastic masuk kedalam tanah dan akan mencemari tanah tersebut akibatnya akan membunuh hewan-hewan tanah seperti cacing. Jenis PCB yang tidak bisa terurai meskipun telah dimakan oleh bakteri maupun binatang manapun, tanaman-tanaman akan menjadi racun berantai sesuai dengan rantai makanannya (Ahmann D dan Dorgan J R, 2007).

Kantong plastic yang sering kita gunakan akan menghambat jalur air yang ingin meresap ke dalam tanah, dan juga dapat menurunkan kesuburan tanah karena plastic juga dapat menghalangi sirkulasi udara yang ingin masuk kedalam tanah, serta menghambat ruang gerak makhluk yang ada didalam tanah. Kantong plastic yang sulit terurai memiliki umur yang Panjang, dan sifat nya yang sangat ringan sangat memudahkan plastic untuk terwaba angin hingga ke laut. Dengan demikian hewan-hewan tanpa sengaja akan terjerat oleh tumpukan plastic yang jumlahnya tidak sedikit, seperti hewan penyu, lumba-lumba, dan anjing laut. Biasanya hewan-hewan tersebut bahwa sampah plastic adalah makanan dan akhirnya mereka tidak dapat mencernanya dan akhirnya mati. Kantong plastic yang telah masuk kedalam tubuh hewan tetap tidak akan hancur manjadi bangkai bahkan bisa berdampak meracuni hewan lainnya. Pembuangan sampah sembarangan ke sungai atau laut akan berdampak bahaya bagi kelestariannya, salah satunya yaitu dapat mengakibatkan kedangkalan sungai dan dapat mengakibatkan penyumbatan aliran sungai sehingga menyebabkan banjir. (Wibowo, D.N).

Maka dari itu penggunaan plastic secara berlebihan akan mengakibatkan jumlah plastic yang terus meningkat, plastic bukan bukan termasuk jenis senyawa biologis, maka dari itu plastic sangat sulit sekali terurai. Perlu waktu bertahun-tahun agar plastic dapat terurai secara sempurna. Kita dapat mengurangi penggunaan plastic agar jumlah plastic tidak terus meningkat.

Dalam penggunaan plastic agar kita dapat memastikan dan mengetahui karakteristik plastic, untuk itu kita harus mengetahui jenis-jenis sampah plastic yang berada di sekitar kita. Berdasarkan American Society of Plastik Industri, telah membuat bentuk dalam system pengkodean resin untuk sampah yang masih bisa didaur ulang (recycle). Symbol/kode yang telah ditetapkan tersebut berbentuk segitiga disertai arah panah yang merupakan symbol daur ulang dan didalam bentuk segitiga tersebut terdapat nomor yang merupakan kode-kode yang dapat di daur ulang, dari nomor tersebut kita dapat mengetahui jenis-jenis plastic yang kita gunakan (kumar dkk \& surono, 2013). 


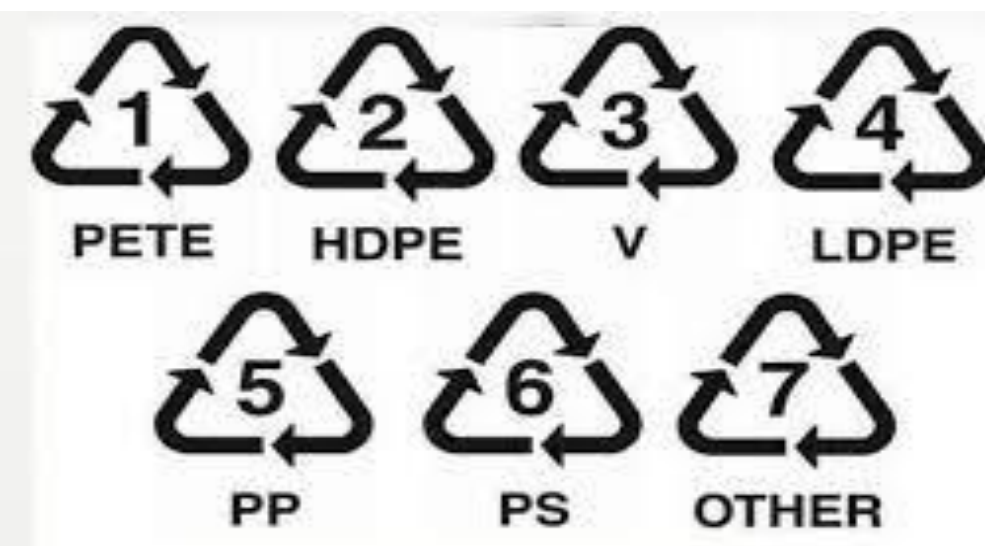

Gambar 1. Kode plastic aman digunaka. Sumber mediainfo.com

Adapun beberapa jenis plastic antara lain yaitu; PETE atau PET, kepanjangannya yaitu polyethylene therephthalate. Jenis plastic ini merupakan jenis plastic yang murah, tidak berat, dan pembuatannya sangat mudah. Adapun penggunaanya terdapat pada botol minuman yang biasa kita gunakan seperti soft drink, ataupun tempat makanan yang biasa kita pakai, dan jenis ini akan tahan dalam microwave. Selanjutnya yaitu HDPE atau high density polyethylene, jenis plastic ini dikenal dengan daya tahan yang kuat dan lebih rentan terhadap korosi, akan sedikit sekali penyebaran kimia yang dikeluarkan apabila digunakan sebagai wadah makan, dan bisa digunakan lagi sebagai wadah shampoo, sabun cuci, maupun kantong sampah, dan jenis ini mudah untuk didaur ulang (Basriyanta, 2007:17).

Jenis PVC atau polyvinyl chloride, pada jenis plastic ini memiliki karakteristik fisik yang seimbang dan stabil. Serta jenis plastic ini memiliki ketahanan terhadap bahan kimia, sifat elektrikm dan juga cuaca. Meskipun memiliki ketahanan yang kuat tetapi jenis ini sangat sulit untuk didaur ulang, sangat sering kita jumpai pada kontruksi bangunan dan pipa. Selanjutnya ada jenis LDPE atau low density polypropylene, pada jenis ini sering digunakan pada wadah makanan dan botol-botol yang memiliki tekstur yang lebih lembek. PP atau polypropylene merupakan jenis plastic yang memiliki sifat kuat terhadap bahan kimia kecuali pada bahan bakar, klorin dan xylene, memiliki sifat insulasi listrik yang cukup baik. Selain itu jenis plastic ini memiliki daya tahan terhadap sterilisasi dengan uap yang panas dan air mendidih. Dan biasanya digunakan pada tempat makan, otomotif, karpet, dan lainya. Yang terakhir yaitu ada PS atau polystyrene, pada jenis plastic ini memiliki kekuatan dan kestabilan yang cukup baik, biasanya diaplikasikan sebagai wadah makan yang hanya sekali pakai, mainan, kemasan, peralatan medis, dan lainya. Dibalik akan bahaya yang ditimbulkan dari sampah plastic untuk itu kita juga harus tahu bagaimana cara untuk mengurangi sampah plastic tersebut. Kita harus membiasakan menggunakan alat seperti kain sebagai pengganti kantong plastic dan jika 
membeli makan atau minum biasakan membawa tempat sendiri dari rumah.

Selain itu limbah plastic juga dapat ditalangi dengan cara Reuse atau pakai Kembali, dalam upaya ini dapat membantu mengurangi sampah, kita dapat menggunakan kembali sampah yang kita pakai menjadi hiasan-hiasan atau hal yang lebih berguna lainnya., selanjutnya ada Recycle atau daur ulang, merupakan upaya mendaur ulang sampah plastic untuk di manfaatkan kembali menjadi plastic kresek hitam atau pot hitam, dengan cara melalui beberapa proses kimia, fisika, dan biologi. Selanjutnya ada Recovery atau ambil kembali, adalah upaya mengambil kembali sampah plastic yang masih memiliki nilai ekonomi yang cukup tinggi, kemudian dikembalikan ke proses produksi tetapi tanpa perlakuan fisika, kimia, dan biologi. Dari ketiganya tersebut biasanya dikenal dengan 3R (Arif Zulkifli, 2014: 106).

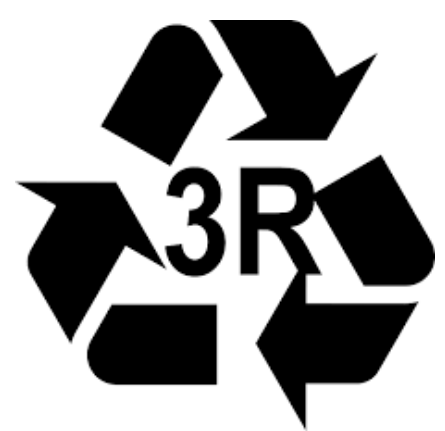

Gambar 2. Teknik 3R. sumber pixabay.com

Kelembagaan dari instansi dan organisasi khusus yang memberikan penanganan khusus mengenai ssampah plastic khususnya barang-barang dari plastic. Kelembagaan ini memiliki peran yang penting dalam menangani sistem pengelolaan sampah plastic secara menyeluruh termasuk didalamnya pada penerbitan peraturan yang memiliki kaitan dengan pengelolaan sampah plastic dan plastic. (Kumar dkk.,2011 dalam Surono, 2013).

Adapun instansi yang terkait dengan sistem pengelolaan sampah plastic ialah Dapartemen perdagangan dan perindustrian yang mengatur secara langsung sistem pengelolaan sampah dari bahan baku ke produk dengan melalui beberapa tahapan. Kementrian lingkungan hidup juga mempunyai tugas dan fungsi dalam pengelolaan lingkungan hiduo termasuk berbagai dampah yang muncul akibat adanya plastic yang telah tak terpakai dan dibuang begitu saja. Pemerintah daerah yaitu Dinas Kebersihan merupakan instansi terdepan dalam pengelolaan sampah plastic dalam sistem pengelolaan sampah yang ada di kota (Isbandi Rukminto Adi, 2002:172- 171). 


\section{SIMPULAN}

Sampah dari plastik merupakan sampah yang dapat bertahan hingga bertahun-tahun lamanya, hingga bisa menyebabkan pencemaran lingkungan. Penggunaan pada sampah plastik sangat tidak bija dilakukan. Jika sampah plastik di bakar maka akan mengeluarkan gas yang akan menyebabkan udara tercemar hal tersebut sanagt membahayakan pernafasan manusia. Jika kita menimbun sampah plastik didalam tanah maka akan banyak sekali dampak yang terjadi yaitu bisa mencemari tanah dan air tanah. Saat ini penggunaan plastik di seluruh dunia sudah hampir sekitar 100 juta ton per tahunnya.

Factor yang menyebabkan rusaknya lingkungan hidup yang sampai saat ini adalah factor pembuangan limbah plastic. Sampah plastic telah menjadi sampah berbahaya dan sulit dikelola. Selain itu limbah plastic juga dapat ditalangi dengan cara Reuse atau pakai Kembali, dalam upaya ini dapat membantu mengurangi sampah, kita dapat menggunakan kembali sampah yang kita pakai menjadi hiasan-hiasan atau hal yang lebih berguna lainnya., selanjutnya ada Recycle atau daur ulang, merupakan upaya mendaur ulang sampah plastic untuk di manfaatkan kembali menjadi plastic kresek hitam atau pot hitam, dengan cara melalui beberapa proses kimia, fisika, dan biologi. Selanjutnya ada Recovery atau ambil kembali, adalah upaya mengambil kembali sampah plastic yang masih memiliki nilai ekonomi yang cukup tinggi, kemudian dikembalikan ke proses produksi tetapi tanpa perlakuan fisika, kimia, dan biologi. Dari ketiganya tersebut biasanya dikenal dengan 3R. Untuk itu, agar lingkungan tetap terjaga kita harus menekankan penggunaan plastik mengingat akan bahaya yang ditimbulkan dari plastik, untuk itu kita harus membiasakan diri agar tidak menggunakan bahan plastik dalam kehidupan sehari-hari. Mulai mendaur ulang sampah plastik menjadi barang yang berguna.

\section{DAFTAR PUSTAKA}

Abbas, E. (2021). Banjir Banua: Menulis Keempatian Banjir Kalimantan Selatan 2021.

Deasy, A. (2020). Studi Efektifitas Bank Sampah Sebagai Salah Satu Pendekatan dalam Pengelolaan Sampah Tingkat Sekolah Menengah Atas (SMA) di Banjarmasin. JPG (Jurnal Pendidikan Geografi), 3(5), 22-37.

Kahfi, A. (2017). Tinjauan terhadap pengelolaan sampah. Jurisprudentie: Jurusan Ilmu Hukum Fakultas Syariah dan Hukum, 4(1), 12-25.

Linda, R. (2018). Pemberdayaan Ekonomi Kreatif Melalui Daur Ulang Sampah Plastik (studi kasus bank sampah berlian kelurahan tangkerang labuai). Jurnal Al-Iqtishad, 12(1), 1- 
19. lingkungan. Indonesian Journal of Urban and Environmental Technology, 8(2), 141 147.

Masyruroh, A., \& Rahmawati, I. (2021). PEMBUATAN RECYCLE PLASTIK HDPE SEDERHANA MENJADI ASBAK. ABDIKARYA: Jurnal Pengabdian Dan Pemberdayaan Masyarakat, 3(1), 53-63.

Mutiani, M., Supriatna, N., Abbas, E. W., Rini, T. P. W., \& Subiyakto, B. (2021). Technological, Pedagogical, Content Knowledge (TPACK): A Discursions in Learning Innovation on Social Studies. The Innovation of Social Studies Journal, 2(2), 135-142.

Mutiani, M. (2017). IPS dan pendidikan lingkungan: urgensi pengembangan sikap kesadaran lingkungan peserta didik. SOSIO-DIDAKTIKA: Social Science Education Journal, 4(1), 45-53.

Purwaningrum, P. (2016++). Upaya mengurangi timbulan sampah plastik di lingkungan. Indonesian Journal of Urban and Environmental Technology, 8(2), 141147.

Putro, H. P. N., \& Jumriani, J. (2020). KEHIDUPAN SOSIAL DAN EKONOMI MASYARAKAT BANTARAN SUNGAI A SEBAGAI SUMBER BELAJAR IPS.

Risma, O. R., Ertika, Y., Zhafira, N. H., Juliansyah, R., \& Affandi, A. (2021). SOSIALISASI SAMPAH PLASTIK DI SMP NEGERI 1 SEUNAGAN KABUPATEN NAGAN RAYA. Jurnal Pengabdian Agro and Marine Industry, 1(1).

Sampah, S. Pengertian Sampah.

Subiyakto, B., Abbas, E. W., Arisanty, D., Mutiani, M., \& Akmal, H. (2020). Sungai dan Kehidupan Masyarakat Banjar: Penguatan Lokalitas dalam Wacana Pendidikan IPS yang Responsif.

Suminto, S. (2017). Ecobrick: solusi cerdas dan kreatif untuk mengatasi sampah plastik. Productum: Jurnal Desain Produk (Pengetahuan dan Perancangan Produk), 3(1), 26-34. 